\title{
Integration in the process of national identity formation for growing citizenship culture of Chinese ethnic in Medan City- Indonesia
}

\author{
Deny Setiawan \\ Citizenship Education Department, Faculty of Social science, State University of Medan, Indonesia
}

\section{Email address:}

setiawandeni2014@gmail.com

\section{To cite this article:}

Deny Setiawan. Integration in the Process of National Identity Formation for Growing Citizenship Culture of Chinese Ethnic in Medan City- Indonesia. Humanities and Social Sciences. Vol. 2, No. 6, 2014, pp. 195-205. doi: 10.11648/j.hss.20140206.18

\begin{abstract}
Indonesian state policies affect the integration and the position of ethnic Chinese identity, one of the ethnic groups in Indonesia. This paper illustrates the factual basis of the perspective of the leaders of ethnic Chinese in Medan, North Sumatra, Indonesia, towards integration in the process of forming national identity in fostering civic culture of postreformation in the city of Medan. The research data was obtained through observation, interviews and documentation. Interviews were conducted by purposive, and documentation studies conducted on the sources of primary data and secondary data. Perspective of the ethnic Chinese characters in his reconceptualization of the integration is leading to the selection of "integrated-pluralism", which is seen as a more appropriate policy in the post-reform building integration in the city of Medan. The synergy of ideas, demands and expectations of ethnic Chinese leaders produce a formulation of a national identity that is more fitting for Indonesia in the era of globalization, namely hybrid identity - "Indonesia, which continues to be". This formulation illustrates a fluid and dynamic identity that leads to the identity of a non-racial nationalism, not rigid and static to changes, developments and needs of the times. Integrated-pluralism and identity of the proposed hybrid ethnic Chinese leaders contributed conducively to the growth of civic culture in the post-reform Medan city, especially in growing participant political culture.
\end{abstract}

Keywords: Identity of the Nation, Citizenship Culture, Ethnic Chinese

\section{Introduction}

The idea of reform in Indonesia are scrolling in May 1998, demanding a favorable change in democratic life. Demands and expectations of changes taking place simultaneously with the tragedy of violence, looting, rape, and murder. This human tragedy, the ethnic Chinese make one of the victims, who were classified as non-natives for this. Discrimination and segregation against ethnic Chinese created from the colonial period through the political Divide et Impera, and continued during the Old Order to the New Order. This situation is accompanied by a variety of policies issued by the regime, which thicken segregation and discrimination to preserve prejudice and stereotypes at the level of private space.

After the riots in May 1998, the Indonesian government pull out various regulations, which repeal discriminatory policies against ethnic Chinese in Indonesia. But still causing many questions about the ease of obtaining the status of citizen of Indonesia. Some experts even prove that in practice in the field of Certificate Holder Republic of Indonesia continues to be asked by employees of the Department of Population to the Chinese people when they wanted to take care of any letter or document relating to the population. Thus, it can be said that the one-party state wants assimilation and integration of the nation, and on the other hand is still ongoing discriminatory treatment either formally or informally. This fact was revealed in a discussion organized by the National Law Commission, on the effort to eliminate ethnic discrimination in Indonesia on 21 April 2003 Frans H. Winarta, advocates and members of the Indonesian National Law Commission, said a number of policies discriminate against ethnic Chinese were issued by the government of New Order is a real form of cultural genocide. Entry Certificate Holder Republic of Indonesia in practice in the field is one of discriminating against ethnic Chinese 
customs, and has become a protracted problem. It shows there are problems associated with the integration process of the formation of national identity. Therefore, the problem of integration in the process of forming national identity, and is still an urgent attempt to do in this era of reform, as input in support of the reform agenda in Indonesia.

Themes of integration and national identity after the reform still needs to be studied, in order to look for ideas and models that fit to foster a culture of democratic citizenship, and the development of a multicultural society. Research on integration and identity of the ethnic of Chinese, with regard to civic culture, has not been done. Studies on civic culture of Chinese people is something urgent to do, because as well as any policy issued in the regime of public space with respect to the integration and identity, still be constrained when the level of private space is not growing culture of citizenship among individual subjects citizens. Efforts to foster a culture of citizenship in Indonesia in the post-reform, is a vehicle for the growth of collective consciousness will remain anonymous, as part of the citizens.

To realize the national integration in Indonesia, has rolled out assimilationist discourse versus pluralist identity in putting minorities. It deals with the application of a postreform policy. Assimilationist policy is an attempt to combine the members of minorities into society by restricting their culture, and require to adopt a system of values and lifestyle of the dominant group or subordination [1]. In contrast to the efforts adopted by the pluralists, where they allow minorities to maintain their culture. There is a difference, if the comparison is made, then the assimilation policies that apply to the Chinese in Indonesia with various tribes. To the Chinese people who have had Indonesian citizenship status, apply policies that are assimilationist, whereas for different ethnic group in Indonesia tend to apply understand pluralist.

The Chinese directed and expected to receive and integrate itself into one of the superordinate group culture, which is one of the culture which is owned by a tribal "Bumiputera" in Indonesia. If both ideologies further investigation, there are implications that arise from both understood earlier, if it is associated with the extent to which the superordinate group is able to implement and allow subordinate groups doing so. The next question is whether the superordinate group believes that minorities will be assimilated ?, Are they still maintain their culture ?, and Is the dominant group can receive many contradictory things that might be done by a subordinate group ?.

The issue of ethnic Chinese in Indonesia is considered important, in line with the emergence of a specific issue, which is known as the "Chinese problem". This problem is an issue that is much talked about Indonesian society, and inevitably, this issue bring up a number of questions, whether ethnic Chinese in Indonesia have to survive on their own cultural identity, or to be integrated into the culture of Indonesia [2]. This question can not be answered finals, because since colonial times until the 1998 reform, ethnic violence - in this case against ethnic Chinese in Indonesia - always repeats occur, as though continue to follow the dynamics of Indonesian history.

Why riots against ethnic Chinese in Indonesia occurred repeatedly? The key word is segregation or separation. Basically, it has become a colonial power intention to prevent inter-ethnic unity. The colonial government monopoly and authority considers that they will be threatened if the various ethnic groups that exist today that combines the strength to fight them [3].

Chinese ethnic separateness of indigenous peoples supported a policy, the social stratification hierarchically divide into three groups, namely the class of Europe, Foreign Orientals class group, and groups of indigenous groups. Each group has the status and rights of different, and in general the Chinese are categorized orientals, are in a more favorable position than the indigenous groups [4]. Therefore, assimilation with the indigenous groups will lead to a decline in social status and at the same time losing its privileges. It shows that the colonial government policy has a great influence, in making Chinese ethnic group separate from the people of Indonesia.

After Indonesia gained independence, the government began a process of indigenization in the economic sector to reduce ethnic Chinese economic power, and develop indigenous entrepreneurs issued Government Regulation No. 10/1959, which forbade the Chinese to trade in the countryside [5]. The ban resulted in the exodus of Chinese people to urban areas, and reinforces the dichotomy domicile. In an effort to build up the strength of the indigenous economy, which is known as the Political Fortress, then issued regulations requiring the government to give priority to indigenous entrepreneurs in the purchase of goods and provision of employment contracts. As a result, many business sectors are closed for Chinese entrepreneurs, and their license can not be extended [6]. This discriminatory policy not only makes the business behavior of the two groups were so separate, but more than that he is getting strengthen solidarity among ethnic Chinese businessmen.

New Order policies do not differ from the Old Order policy. In public spaces, New Order requires the assimilation policy, but in the private space community still discriminated. Within certain limits, the New Order tends to apply legal equality policy rather than a policy of coexistence of the Chinese ethnic minority groups. This legal equality is a hypocritical policy, because although there is recognition in the public space of equality, but in fact there is a private space hostility towards ethnic minorities. Legal equality is ambiguous policy, on the one hand, establishes legal constraints against formal discrimination against minority organizations, and on the other hand receive informal discrimination in inter-personal relationships with individual ethnic minorities [7]. Indonesian government has taken a policy contributed to the separation of ethnic Chinese. Interethnic conflict in Indonesia is more related to government policy. Government is an actor who has a central role in the process of social integration. But in private-space, the individual as a citizen also has a vital role in supporting the 
creation of inter-ethnic relations are integrated.

Search for identity of the Chinese in Indonesia are faced with several options, namely to be Indonesian, Chinese or adopt fixed identity [8]. However, these options are not always placing the Chinese in easy circumstances. Option with the identity of Indonesia, New Order Government has facilitated the assimilation imposes incorporation for the Chinese people, to eliminate its Chinese identity and become Indonesia. Motivation imposition of assimilation incorporation seems more nuanced punishment for suspicion of involvement in the uprising of the Chinese Communist Party of Indonesia in 1965. This policy contributes to a variety of insecurity and social unrest of concern such as prejudice, violence - mass violence targeting ethnic Chinese. And leaving the trauma for these minority groups, in addition to due to various acts of violence they experienced, as well as a result of discriminatory treatment which binds movement of Chinese people's lives [9]. If they choose to keep their identity as a Chinese, is also not an easy matter, because it's all Chinese closely with a variety of images that are less favorable in the eyes of the indigenous ethnic and government bureaucracy. Internally among the Chinese community itself is also a shift in understanding the meaning of Chinese identity itself in the format change.

The shift occurred from the traditional Chinese characteristics, ethnic-oriented and old country, a feature of modern Chinese, national and local oriented $[8,10]$. Associated with efforts to leave the trauma of the past, where the Chinese identity oriented culture ancestral land, often stuck on matters of political nuances. For example, when the relationship between Indonesia and China deteriorated. Chinese ethnic as ethnic minorities also often disadvantaged in the context of minority-majority relations. Ethnic minorities are always the target of prejudice and discrimination from the majority. Position as a minority however always vulnerable, be it in a weak position as a minority and a strong minority.

From a variety of pressures and uncertainties, many Chinese people are at a crossroads. It is at least illustrated by the findings of the study by [8], which indicates that this is now developing a variety of orientations identification among the Chinese in Indonesia. There are at least four orientations were found, namely the first group, are those who believe that they are ethnic Chinese, and will always be ethnic Chinese. Therefore, in identifying themselves, they always come back to the origins and heritage of Chinese culture. The second group are those who feel has been successfully assimilated into Indonesian society. They are the ones who feel ethnic origins and their culture is the curse that complicate their position to become an integral part of the community. The third group are those who believe that they have exceeded their ethnicity, the state and the nation, which has become a globalist and internationalist. While the fourth group, are those who tend to think that their lives are determined by their work, so they prefer to avoid identifying themselves as culturally and politically.

Aspirations and political participation of the Chinese turned out disaggregated into five groups perspectives: first, that feel the need to highlight their ethnic identity and fight for their rights as a group, ie by establishing Chinese Party. Second, those who do not want to make ethnicity or religion as the basis of the movement, but rather through the platform of equality, namely by setting up a national unity party. Third, which is more like a forum whose main purpose is more than a pressure group. Fourth, the forming community groups because they feel the same boat, which established the Social Circle Indonesian Chinese surname. Fifth, who joined the political party that is open as PDI-P (Partai Demokrasi Indonesia Perjuangan), PAN ( Partai Amanat Nsional, etc. [11]. Dynamics of Chinese ethnic identity search in Indonesia has grown through new subcultures which is a response to the social reality that describe the plural ethnic Chinese identity.

Indonesia entered the era of reform towards a more democratic life. The process of "nation and character building" that has been started since the proclamation of August 17, 1945 through the era of President Sukarno and President Soeharto, have ups and downs with all its strengths and weaknesses. The process was continued in the era of the transitional leadership of President BJ Habibie and legitimate leadership era President Abdurachman Wahid, President Megawati, and President Susilo Bambang Yudhoyono. Democratic values in the life of the nation of Indonesia back into a central point. The word democracy refers to the concept of state or public life. Adult citizens participate in government through elected representatives. The government encourages and guarantees freedom of speech, religion, thought, association, uphold the rule of law. Majority government to respect the rights of minorities; and the people give each other the same treatment [12].

Transition from nondemocratic governments towards democratic government, is a complex process and involves a number of stages. Of the background conditions of national unity, this process through three stages. First, the preparation phase which is characterized by a political struggle to bring down the nondemocratic regime. Second, the decision stage, where elements of democratic institutions has been formed. Third, the consolidation phase, where democratic institutions and practices ingrained in the political culture [13]. The fundamental requirement of democratic consolidation democratic institutions and practices that have been entrenched. Efforts to cultivate democratic political or civic political culture is an absolute necessity. Development of democracy depends on a number of factors ie the degree of economic development, a sense of national of national identity, and the historical experience and the element of civic culture [14].

Civic culture and history have contributed to the development of democracy. Experience the history and culture of citizenship provides a strong foundation for the growth of democracy, which is a consolidated democracy. Civic culture is a culture that sustains containing citizenship, ie a set of ideas that can be embodied in cultural effectively representations for the purpose of Shaing civic identities. 
Civic culture with respect to the individual psychosocial adaptation of communitarian cultural ties (family, tribe, local communities) to the citizenship of a country's cultural ties [15]. Civic culture can be a deciding factor for the creation of democratic consolidation. Development of civic culture is a necessary orientation because in the civic culture, aspects of political are, namely (1) micro-political aspects (political level on the individual), (2) the political aspects of the macro (national political systems), which are interrelated. Political orientation on micro-political aspects, regarding the political orientation parokhial as sub-culture, the power of the individual to religion and ethnicity, as well as the orientation of the participants with regard to the active and rational actions of individuals as role culture. While the macropolitics, especially with regard to the political orientation of loyalty to the national political system, trust and obedience to government [16]. The elements contained in the political orientation of civic culture is necessary for the development of a democratic political system and stable. The civic culture can be a bridge between the micro with the macro politics [17]. In the micro level that is how the identity of individuals who are bound by the Communitarian culture can put themselves and in conformity with the political system in the nation-state. In the development of civic culture with regard to the character of the nation, which includes civic disposition, civic commitment, and civic participation. All three of these components contained in the core of civic virtue as a democratic civilization. In the process of growing civic culture, individuals who are in Communitarian culture, as citizens, can be compatible in harmony with the political culture that is supported by civic virtue as the essence of democracy [18]

Perspective of the Chinese characters that were examined in this case is related to the idea, the demands and expectations regarding integration in the process of forming national identity after the 1998 reform with regard to the growing efforts of civic culture. Which is used as the theme is (1) reconceptualization of the integration of post-1998 reform, (2) the formulation of national identity in the era of globalization, and (3) the growth efforts of civic culture in the era of democratization.

\section{Methods}

This study used a qualitative approach to grounded theory method. Theory inductively derived from the study of the phenomenon described [19]. Data were collected through the study of documentation, observation, and interviews. The subjects of the research done purposively [20, 21]. Determination of the study subjects were purposively intended to be able to capture the data as much as possible in all its complexity. The criteria used in the determination of the research subject, namely setting, actors, events, and process [22].

This research subject Prominent ethnic Chinese in Medan on the situation post-1998 reform as a venue for the data collection process. The figures are ethnic Chinese who have a major role, in relation to the focus of this study, which play a role in carrying the reform of agenda in the political, economic, social and cultural. Based on careful observation, researchers focused on the selection of research subjects continuous phase adjustment or focusing [21], which is then set as the subject of research focused on the six ethnic Chinese leaders have a role and influence in the life of the city of Medan.

Data were analyzed by using the analytic comparison, which includes the method of agreement and method of difference. Data obtained, then compared and then sought its suitability to address questions of research [23].

\section{Results and Discussion}

\subsection{Construction Integration}

The Six figures of ethnic Chinese from Medan city have a different perspective of integration with respect to construction. Post-New Order has brought back the discourse of assimilation versus integration. It is intended not to choose, but to review and perform appropriate constructs for the integration of the Indonesian nation. There are different views and ideas from them. In general, these ideas have in common perspective that puts the unity of Indonesia as a destination in the frame of Unity in Diversity (Bhinneka Tunggal Ika).

The synergy of ideas that was brought into the six figures, to produce a concept of integration that is more fitting for Indonesia in the post-reform. The concept was proposed by the name of integrated pluralism, a concept of "diversity are united on the basis of respect for the differentness". The idea of integrated-pluralism as a policy which is a synergy of several models (natural assimilation, integration strategy, integration-assimilation, cultural integration, unity of Indonesia, and multiculturalism). It shows the ethnic Chinese society itself has grown a growing social reality and increasingly describe the plural ethnic Chinese identity. For the integration of coexistence (cultural pluralism) in the integrated corridor pluralism is most needed strategy for Indonesia which polyethnic.

Integration in integrated corridor pluralism, means integration acknowledge and pay homage to the identity of each entity. Every individual basically want to have a positive social identity through recognition and social equality [24]. Recognition and social equality is what is the integrative efforts in supporting the process of forming national identity. Recognition of the differences in effect lead to the recognition of human rights to have their own culture that needs to be recognized by other communities [25].

Departing from the conception of integration in integrated corridor pluralism, there are two strategies have been proposed [26], namely the concept of assimilation and pluralism concept. It reconstructed by asking the question, "Forms of assimilation and pluralism as what fits with the post-reform conditions in Indonesia?" Structural assimilation, seems to be an alternative in building integration in Indonesia. 
Structural assimilation is often also referred to as the integration, which is a situation that gives the opportunity to participate freely in all forms of social interaction, without questioning one's ethnicity. With such integration, culturally ethnic groups maintained, and vertically happen equation in politics, economics, and others. While the form of pluralism is an alternative option is cultural pluralism, which has implications for the maintenance of various cultural systems within the framework of the general political and economic [27]. Each of group ethnic should be free to determine how many of the elements of their ethnic heritage that will keep them maintained. The minority ethnic groups want equality in its capacity as a citizen with the majority ethnic group, but still has its own culture.

The perspective of leaders of ethnic Chinese in Medan city with regard to the post-reform reconceptualization of integration, it seems the idea, the demands and expectations they can be input means for the Indonesian government in formulating policies that ever existed. The ideas, demands and expectations, can be reconseptualisized integration perspective in the post-reform, namely: First, the integration is needed for the community can be applied through the assimilation model of coexistence of nature as a policy that can protect all cultural identity is so diverse and different. Through this model, the behavior would understand and accept diversity and ethnic diversity, mutual respect, solidarity in all spheres of life, and senses of belonging to all existing identity as belonging to the Indonesian nation is transmitted. The concept of "natural assimilation" begins with the fact that the long history, the Chinese migrants came to the archipelago and meet with the original residents. They blend in harmony. But when it comes to the imperialist policy that is based on race, has differentiated the position and the role of the people in the archipelago. The impact of racism and discrimination is still felt to this day. The concept of natural assimilation in need of engineering application remains fixed engineering program is designed to eliminate racial prejudice, deconstruct the values stereotyped, and discriminatory behavior. Modified was within the framework of Pancasila and Unity in Diversity. Application of this model requires "the elimination of discrimination". Therefore, the action which is considered, the most powerful methods in teaching pluralism, should be escorted by example and role model, so that discrimination has become a chronic disease can gradually eroded in building integration. The contributions of this demand, will bring hope for the realization of "public anti-discrimination".

Second, the integration strategy seems to have been initiated previously adapted to the natural Indonesian reformation era, that is a reasonable integration, which nonras, which recognizes all the tribes in the archipelago as part of the Indonesian nation, including ethnic Chinese halfbreed. To achieve this, all members of the community to interact openly with each other to fill the need, not hinder each other, and that is important there is a consensus, that consensus on the concept of a more modern Indonesian nation. The concept of the Indonesian nation is no longer smell the race, but the concept of Indonesia which is placed within the limits of the political sense, that is a true citizen of Indonesia visits instead of offspring. This demand clearly requires the abolition of racism, which will bring the hope, that all tribes in the archipelago united and integrated build one Indonesian.

Third, combining integration with assimilation strategies simultaneously, which is an alternative idea that can be input. Indonesia, which consists of hundreds of tribes seen through integration approach, which is a strategy that requires all tribes into the mainstream of the nation of Indonesia. However, it must be functional integration, ie to unite which constituted with the interdependence between the parts in a social system to realize the unification of the harmony. But on the other hand, the tribes in the archipelago is also naturally related and combine to form a new group, the bigger, the Indonesian nation. The proposed functional integration and assimilation chosen is kind of amalgamation. The demands of this type of model is to avoid actions that are hegemonic. Through such demands, is expected to awaken the clean Indonesia democratic of any form of discrimination, poverty, corruption, ignorance, and injustice.

Fourth, raised the idea of cultural integration to be constructed in the building integration of the nation, became the next alternative ideas. The reason is, legally and politically, there is agreement on the basis of national integration built equality and equality. But culturally, especially in people's lives, not an agreement as a whole. Perhaps this is due to the influence of colonial politics of law and entrenched long, the impact of values prevailing in each group in society become contested. The idea of building a culture of integration is to lift the injustice that is still ongoing to be removed, including gender inequality. Gender inequality is the result of socio-cultural construction, which resulted in women placed in a subordinate position and marginal. There is a kind of blue yarn, gender struggle in identical with the struggle in building cultural integration. The struggle for gender is to build a culture that is willing to accept and appreciate differences in togetherness. Hope that fought in building a culture of integration, namely the integration on the basis of equal rights and equality.

Fifth, rejected the term integrationist and assimilationist, because the two terms were already flawed politically, into the background of the idea to use the term unity of Indonesia which is deemed fit more clicking Indonesia. Strategy concept of the unity of Indonesia, is reflected in the motto Unity in Diversity (Bhinneka Tunggal Ika). Indonesian society consisting of diverse ethnic and cultural unity without eliminating cultural and ethnic identity of each component of society. So the concept was clearly not based on race, but that there is a nation of Indonesia. Nation of Indonesia is a mutual agreement to realize the unity of Indonesia. The idea of this concept of the unity of Indonesia, demanding the construction of Indonesia based on democratic unity. Unity is disturbed, because in practice not used to implement democratic values. There is equality, both political, sociocultural, and economic. When the values of democracy is 
already entrenched, it will grow healthy political, sociocultural harmony, and a strong economy. But of the three factors (political, socio-cultural and economic), the dominant economic factor as a determinant factor in building democracy. To the idea of the unity of Indonesia in the era of reform and globalization need to prioritize economic development, especially in the gaps. This demand leads to expectations of Indonesian Association of welfare, prosperity.

Sixth, the integration is constructed not by ethnicity and religion, but is built on a political consensus on the basis of differences and appreciation. So far, only invited to learn about diversity, but diversity and appreciation is not taught grassroots. Understanding, appreciation, and assessment of other people have made cultural trend. It shows the integration of the nation it was time to put in the frame of multiculturalism. Multiculturalism as a social practice and government policy, which has become a worldwide trend. Multiculturalism is essentially meant to create a sociopolitical context that allows individuals to develop health identity, develop inter-group attitudes are positive, and the establishment of democracy. Democracy demands of the model of multiculturalism is the elimination of ignorance as the cause thickening of discrimination in all areas. This demand is expected to lead to the establishment of a democratic multicultural society, are willing to accept the differences and appreciate the differences in the diversity.

\subsection{Formulation of National Identity}

Ideas, demands and expectations, the figures relating to the theme of ethnic Chinese "national identity formulation" is also different. But the only difference lies in the groove to think not in terms of the principle. Each figure remains in the estuary that is the nation of Indonesia. There are different views and ideas of the above six figures of ethnic Chinese, but in general, these ideas has in common perspective that is the understanding, appreciation, assessment and appreciation of different ethnic identities. Recognition of the position of his identity as an integral part of Indonesian national identity. This recognition brings with her identity to be able to put themselves in harmony in a larger identity, the identity of Indonesian nationality. The synergy of ideas that was brought into the six leaders, resulted in a formulation that national identity is more fitting for Indonesia in the era of globalization. The formulation proposed by the name of a hybrid identity, namely Indonesia, which continues to be. This formulation illustrates a fluid identity, open, dynamic that leads to national identity that nonras, not rigid, not stiff, not closed, and no static to change, progress, and needs of the time. For them, the characteristics of Indonesian identity is the identity that continues to be.

Based on this, it appears that the identity of the multiple addition affected by state policies are also affected by various events. Talk about a single identity for ethnic Chinese is useless if the identity itself can be affected by a variety of political, social, economic and others faced by a person at a given time. Reviews of these findings clarified by [28] that the Chinese people face an important choice, which is to choose the orientation of his life, but it is very difficult, to do. There are four kinds of options for an ethnic Chinese. First, they still choose their home country's history. Secondly, Those who choose local history as the orientation (in this case the history of Indonesia) with all the implications that it faces. The third option, they are Likely to choose the history of the world. It is possible in the current situation of globalization. The fourth option, they will draw on its history. This means that not only Chinese history, local history, but there are various kinds of history in itself [29].

The above options have an impact on Chinese identity in an increasingly global era depicting plural identity, multiple and varied. The term was clarified by providing information, that dual identity is not a situational identity or alternative identity, can be changed or removed and disposed of by the person concerned. Dual identity is the simultaneous presence of various types of identity, for example: ethnic identity, national identity (local), cultural identity and class identity. The identity of the fourth respectively supported by the norm. The identity of the Chinese people today are divided into four groups, namely: (1) physical norm, which is determined by endogamis marriage; (2) political norms, which refers to the notion of political loyalty to the state, the need for commitment and participation in nation-building tasks; (3) economic norms, which refers to the behavior of a rational and modern standards, which affect the behavior of the national economy, and the standards that govern each group effort in making a living and wealth; and (4) cultural norms, which are defined broadly encompasses all things in the country and the society that affect the entire system of the value of each person [30].

It describes how the dynamics of the search for identity in Indonesian ethnic Chinese. In the reality of history and the reality of the ethnic Chinese community, developing new subcultures which is a response to the social reality. The response not only to the state policy of Indonesia, but also to the various events that developed. This factual overview and shows the search for identity that carried the ethnic Chinese leaders, which is the result of the policy response to the state and various events. The globalization and events of reformation that occurred in the State of Indonesia, has opened up a variety of opportunities to the positive identity position. Perspective of leaders of ethnic Chinese in Medan city with regard to the formulation of a national identity, it seems the idea of the demands and expectations they can be used as input means for the city/ state in the formulation of national identity in the space back to the Indonesian-ness in the global era, namely:

First, the proposal to enable dynamic identity as an open identity, which is naturally in the flow of changes both internally and externally. This proposal can be a valuable alternative input. Especially in the era of globalization, local communities faced with two sides that should be complementary, ie, conscious that they must adapt themselves to the changing world, and at the same time they were conscious to maintain continuity and identity. This condition is often referred to a dynamic equilibrium. Within 
the framework of dynamic equilibrium, then the word "identity" is not static but a dynamic process based on the particular social context. This dynamic identity model, demanding the concept of nation is no longer defined by race, but by political means a mutual agreement to build Indonesia identity continues to be. This idea demands for the abolition of majority-minority category, which in the history of the State of Indonesia has bring up the dividing line between insiders and outsiders in their interaction relationships that are not aligned. With this demand is expected to appear in the harmonization of inter-ethnic relations in its Indonesian mosaic colorful.

Secondly, the proposal to continue to build a national identity $($ local $=$ Indonesia) who hold political norms. This identity characterizes itself in political norms that require the full support of all state institutions. In the context of modern political norms, identity refers to the notion of political loyalty to the state. Sense of belonging and sense of solidarity is a form of loyalty to build Indonesian nationalism. Nationalism does not recognize ethnic and religious, because Indonesian nationalism is love of the homeland. Indonesian nationalism is not exclusive but inclusive. This means all the tribes in the country and Indonesia have equal opportunities in building the homeland of Indonesia. The identity model, demanding the abolition of various diseases is still attached to the perceived culture, such as: prejudice, stereotypes, discrimination, scape goating, ethnocentrism and racism. Expectations of these demands crave to achieve Indonesia Unite.

Third, the proposal to prioritize the construction of cultural identity in formulating keidentitasan Indonesia. This proposal can be a positive input. However, the model's identity needs to be supported by the adaptation strategies of each individual citizen. This means that individuals who are in Communitarian culture can place his or her identity in harmony with the political culture in a nation-state. Model of cultural identity, emphasizing the preservation and peculiarities of cultural values. The idea of this idea can be realized through cross culture fertilization, in which two or more different cultures can share cultural values through a typical simultaneously preserve cultural ties. The identity model requires the elimination of discrimination in the field of political, economic, social, and cultural main. Through these demands will awaken a growing expectation values of a democratic culture in a pluralistic society.

Fourth, the proposal to put the social identity on the basis of tolerance of different identities. This model gives freedom to the individual to have a positive social identity. Efforts to achieve a positive social identity can be achieved through social mobility and social change. Mobility and social change in question, hinting every individual citizen qualified to be able to do a shift in values or orientation toward change for the better. Changes in value or change orientation is a positive image as a strategy to adapt to the ever changing era. But the changes were not meant to leave at all something old. The ethnic whatever is in the archipelago when doing the transformation, does not mean leaving the typical values being identified. Whatever form it changes, each entity must still hold on to the values of shared identity, namely the values of national identity that belongs to all identities that exist in the archipelago. The identity model requires the maintenance of inter-ethnic tolerance in relation to mobility and social change, as well as in the face of change itself. Through these demands, expectations will materialize birth of the New Indonesia, in the sense of Indonesia continues to be.

Fifth, an alternative proposal to submit a class identity in the formulation of national identity. The identity of the model rests on economic norms. Motivated by the circumstances of the times and globalization are increasingly intense, demanding Indonesia to be able to work together with other nations, which means requires all citizens to have bargaining power, oriented achievment and foster productive behavior. National identity would have bargaining, if supported by a strong economic strength. The identity model requires all citizens to have the orientation of productive attitudes and behavior, to build a wish for a prosperous multicultural society.

Sixth, the proposal to put the multicultural identity in the formulation of national identity in the global era is full of paradoxes. The meeting between global values-mondial versus local values, requires all citizens to learn to dive: to understand, to appreciate, to assess and to pay homage to any existing identities in multicultural societies. Multicultural identity born of mutual respect between the owner's identity is a major force as a base the birth of a multicultural society. Awareness of identity like this does not appear out of nowhere, but born of a learning process that is capable of promoting multiculturalism values of unity through: respect for ethnic identity / culture of others; respect and curiosity about other ethnicities and cultures; and feel happy and participate maintain ethnic diversity / cultural as part of the community. Unfortunately, the post-reform era has emerged phenomenon of regional autonomy of ethnic politicization that had implications for future generations. For this model requires the abolition of the politicization of ethnic politics in practice, through multicultural learning to build a national identity multi-cultural insight.

There are the different ideas, demands and expectations of the above six ethnic Chineses' characters. But in general, these ideas have in common perspective that is the understanding, appreciation, assessment and appreciation of different identities, as well as recognition of the position of his identity as an integral part of Indonesian national identity. This recognition demands bring identity to put themselves in harmony in a larger identity, namely the identity of Indonesian nationality.

\subsection{New Social Space of Chinese Ethnic in the Growth Efforts of Citizenship Culture}

Efforts growth of civic culture, each character with background work and competence, has chosen a path that is considered appropriate as container growth of civic culture. One thing that is interesting to the case of the city of Medan 
is passion ethnic Chinese characters in entering the political arena. This case there are several reasons: First, maybe some of the ethnic Chinese leaders want to make their devotion to Indonesia more perfect, by integrating socio-economic devotion that has been achieved during this to dedication in politics, through formal politics. This is a concrete form of political participation because for decades the political rights they have been deprived by the state.

Second, the anxiety associated with a number of Chinese people who are successful economically, but still a lot of social inequality and the policies that are not public welfare. Most of them have jumped into the world of non-political organization. Together small people, they fight for a better life and some choose to plunge into practical politics by joining a political party. The leaders of ethnic Chinese in Medan are sure, that the post-reform today can fight for the welfare of the people by creating or revising government policies perceived unfair.

Third, statistically, the number of ethnic Chinese society today is quite significant both at the level of North Sumatra and in the city of Medan. Of the 12.8 million people of North Sumatra, about 1.04 million of whom are ethnic Chinese. Meanwhile, of the approximately 2.1 million residents of the city of Medan, about 500,000 people or 25 percent are ethnic Chinese. These data indicate that in terms of the number of significant and reasonable when the Chinese community have their representatives in the legislature.

This phenomenon showed the excitement politics of ethnic Chinese in North Sumatra, especially in the city of Medan, the which in recent years is considered increasing. This phenomenon should be seen as a positive and concrete forms of political participation of ethnic Chinese in Medan and build together. Also one thing to note, state policy was very influential on their role in a space. If the first, the ethnic Chinese economy is limited in space, but now comes the interesting phenomenon, they had dared to enter the public spaces, especially the political space that used to be considered the most taboo to be approached. This data indicate a shift from a closed space towards the opening of social spaces, are the new things to them.

As an ethnic Chinese characters, they appreciate the public spaces are different. But there are similarities in the service as a citizen, that foster a culture of citizenship that "democratic" through a real form of "participation". These findings can be clarified with reference to the classification of political culture as described [17], namely (1) parochial political culture, which is a very low level of political participation, which caused cognitive factors (eg, relatively low levels of education); (2) The political culture subjects, which are already in a relatively advanced society (social and economic) but still is passive; and (3) the political culture of participants, namely political culture characterized by a very high political consciousness.

Adhering to the above classification of political culture, the political orientation of the six ethnic Chinese figure in the case of this study, it can be inserted to the classification of the political culture of the participants. They appear as active citizens, have the competence and skills as citizens, participate actively in political activities, and act as an activist in public life. Real behavior exemplified by the figures, is a form of himself as a citizen participation in political life, as well as their real effort to foster a culture of citizenship. [15] describes the civic culture, emphasizing the importance of the participation rights of citizens to take decisions relating to various aspects of the public interest. Such participation should be built on fundamental matters, namely: (1) egalitarianism or reciprocal relationship horizontally fellow citizens; (2) pluralism, where disagreement, beliefs and interests of fellow citizens is accepted as a fact of life that must be respected, because of socio-political tolerance characterize crucial to the civic community; and (3) mutual trust and solidarity among citizens [30].

Profile's ethnic Chinese leaders, need to be used as an icon for the citizens of the people of Medan city. Its' goal is to involve more citizens who have contributed to the growing efforts of civic culture, especially the political culture of the participants who contributed to the development of democracy and the growth of democratic multicultural society. Civic culture is one of the elements that affect the growth of democratic development. In the civic culture itself there are elements of civic virtue that include: the active involvement of citizens; relationship equality, mutual trust, tolerance cooperative life, solidarity, and community spirit. Civic culture can serve as a cultural agreement to establish the degree of inter-ethnic harmony is quite steady.

Based on this idea, the demands and expectations of the proposed leaders of ethnic Chinese in Medan, it can be stated that: the need for the development of a multicultural society in Medan through the city's cultural development together. Vehicle to develop learning multiculturalism needs to be strengthened with the policies issued by the regime by presenting multicultural education in institutions. It was important, because the multicultural education as a vehicle for learning multiculturalism is essentially a set of beliefs that recognize and assess the importance of cultural and ethnic diversity in shaping the lifestyle, social experiences, personal identity, educational opportunities of individuals, groups and nations [31]. This multiculturalism function with social action approach of multicultural education, teaching the learners become critical citizens, active, and as an agent of change, as well as competent leaders in different communities are ethnically and culturally pluralistic. It becomes an important point in the learning activities in all educational institutions.

Learners' competence development is characterized by the above multicultural citizens, become an integral part in the development of multicultural citizens. Multicultural citizenship competence decomposed into: (1) Civic knowledge, relating to the content or what is supposed to be known by the citizens; (2) Civic skills, are the intellectual and participatory skills relevant citizens; and (3) Civic disposition that hinted at a public or private character that is essential for the maintenance and development of 
constitutional democracy [32].

Synergy link of the three competencies, forming civic competence with personal qualities desirable goal that qualified citizens (competent, confident and committed) which has a civic virtue, civic culture, as well as the values and beliefs of democracy towards the formation of personality that has a sense of social responsibility and nationality [18].

The above description, obtained factual description that the profiles of the six ethnic Chinese figure in the case of this study, with its civic competence able to enter the classification participant political culture. Democratic values which they apply coupled with concrete participation in public life, an indication of the growth of multiculturalism in the city of Medan. In the spatial context, before the reform they are patterned on stagnant space (economy), they now have the freedom to choose the room. New social spaces, their appreciation because there is respect for different identities. But any commitment they have shown, how the identity attached to it, can be placed in harmony in a larger identity, namely the Indonesian national identity (political culture).

Their own civic competence embodied in the political culture of the participants, which is a response not only to the state policy but also against a variety of events, including reforms that open up opportunities for them. They seize the chance and opportunity through social mobility and social change by proving his identity as an integral part of Indonesian nationality. The success of several prominent ethnic Chinese in mobility and changes to the post-reform multicultural society, not just the luck factor of the circumstances that gave him a chance. Identity theory viewed the success of one's identity, one of which, is determined by its ability through the process of social comparison in order to gain recognition from other parties and social equality. Social comparison as a way to determine the position and status of social identity, is a learning process that requires the individual's ability to adapt [24].

In the context of social learning theory, adaptive learning process designate the ability of individuals trying to free themselves from the problems that press. They are trying to get out of the suffering experienced and strive toward better [33]. This is shown by the figures of post-reform ethnic Chinese in Medan are trying to penetrate the barriers of ethnic and space. In fact, they were doing generative learning, as a learning process to obtain and realize what they want, such as: vision, objectives and targets. This is evidenced by the figures by holding positions in the government elite. Referring to the social learning theory, several prominent ethnic Chinese, became an icon of pluralism, which is a model that can be used as a social learning for the citizens of the city of Medan, in building a multicultural society. On the other hand, the construction of a multicultural society through multicultural education needs to be supported by elements of civic culture as a systemic program of social learning, especially in growing participant political culture that led to the development of a democratic multicultural society.

For these three themes, the reconceptualization of integration, the formulation of national identity and cultural citizenship related to competitiveness functionally. The idea of integrated pluralism proposed as an alternative to policies that brought recognition and difference, enabling the functioning of dynamic identity, "hybrid identity: Identity of Indonesianness continues to be". Functional relationship of this theme to create conditions conducive for the growth of civic culture, political culture main participants. This condition is used by the townspeople as an opportunity to develop civic competence through multicultural learning and social learning in building a democratic society, multicultural city.

\section{Conclusions and Recommendations}

\subsection{Conclusion}

The reconceptualization of integration theme, national identity formulation and growth of civic culture provides the following conclusions: (1) Integration of reconceptualization obtained from the model: natural assimilation; integration strategies; integration-assimilation; cultural integration; Indonesian unity; and multiculturalism, in a synergy in producing " the integrated pluralism" as a policy alternative, is deemed more suitable for the conditions of post-reform Medan 1998. The idea of integrated pluralism brings recognition and the difference in the frame of national unity based on "Pancasila". Integrated pluralism as an idea, motivated by the demands and expectations of leaders in building for the future integration of the city of Medan. The demands of the six of leader is a critique of past conditions, as well as efforts to eliminate: discrimination; racism; hegemonisme; injustice; gaps; and ignorance. The six of demands born of a hope for the future of the city of Medan, namely: community anti-discrimination; Indonesian nationalism; Indonesian democracy; equality and equity; Indonesia prosperous; democratic and multicultural society. (2) Formulation of National Identity can be achieved from the model: dynamic identity; national identity; cultural identity; social identity; class identity; and multicultural identity, in synergy to produce "hybrid identity: Identity of Indonesianness continues to be". Hybrid identity, namely the identity of the "Indonesia continues to be", ie as the idea of the figure in the reconstruction of the nation's identity. It is deemed more appropriate to build the identity in the era of globalization, but remained in the room to the Indonesianness. This is an attempt to remove: the category of majorityminority politically has spawned the dividing line; remove various diseases culture (prejudices, stereotypes, scape goating, racism and ethnocentrism); eliminate discrimination in the political, economic, social and cultural); build tolerance; build productive attitudes and behavior; remove the politicization of ethnicity. This gave rise to the expectations, namely: the establishment of harmonization; Indonesia united; the growth of the values of a democratic 
culture; New Indonesia (Indonesian to be); prosperous multicultural society; keidentitasan insightful and multicultural nation. (3) Growth opportunities Cultural Citizenship functioning of dynamic identity. Functional relationships of these two themes, creating conditions conducive to the growth of the political culture of citizenship. In the context of civic culture, the six of character of post-reform ethnic Chinese in Medan able to enter the classification of participant political culture. The role of leaders with regard to the growing efforts of civic culture in the city of Medan post1998 reform, used by leaders to take the opportunity for social mobility and change. Social comparison, social learning and multicultural learning, they use to develop civic competence in building a democratic society, multicultural city.

\subsection{Recommendations}

Some things are recommended, namely (1) that the decision makers of Medan city government in determining policies, especially those related to the integration program in the process of formation of national identity, should be able to formulate the integrated pluralism which conducive to grow the identity fluidness, which is dynamic in the face of development, changes and needs of the times. Formulation is formulated to build a national identity that continues to be identity of Indonesianness. (2) that all institutions of Medan city agreed together to establish a culture of citizenship as one of the elements of democracy, as a systemic program in building a democratic society, multicultural city. This can be done through multicultural education as a vehicle for learning systemic multiculturalism and social learning to improve the civic competence of citizens of the city of Medan. (3) that the citizens of the city of Medan can learn to dive; know, understand, appreciate, assess, and appreciate the existing identities, so intertwined harmonious inter-ethnic relations on the basis of recognition and difference. The initial step is conducive to building a democratic society, multicultural city. (4) that the Community of Scholars of Social Science Education, especially in college educational institutions, in the building of Social Sciences Education as synthetic dicipline and as educational disciplines, to establish the theme of integration, identity, and civic culture as essential themes in social studies learning based multicultural. (5) that the practitioners of Social Sciences Education, Citizenship Education particularly well in primary education, secondary and higher education in fostering a culture of citizenship, should be able to reformulate the civic competence in the global era in order to form and produce young people who have the civic knowledge, civic skills, and civic disposition.

\section{Acknowledgements}

The author would like to thank Mr. Hamonangan Tambunan, Lecturer in Education Department of Electrical Engineering, Faculty of Engineering, State University of Medan, for his assistance to the author.

\section{References}

[1] Wirth, L. (1945). "The Problem of Minority Groups", The Science of Man in the World Crisis, R.Linton (ed.). New York: Columbia University Press.

[2] Blusse, L. (1991). The Role of Indonesian Chinese in Shaping Modern Indonesian Life, in Indonesia, Cornell Southeast Asia Program.

[3] Simbolon, P.T. (1991). Tapping on the Wall: Ethnicity and Marketplace Trade in the Urban Context of Jakarta. Amsterdam: VU University Press.

[4] Coppel, C. A. (1993). Indonesian Chinese in Crisis. Kuala Lumpur: Oxford University Press.

[5] Mackie, J.A.C. (1976). "Anti-Chinese Outbreaks in Indonesia, 1959-68", dalam J.A.C Mackie (ed.). The Chinese in Indonesia: Five Essays. Melbourne: Nelson.

[6] Suryadinata, L. (1997). Cina Perantauan. Majalah Mingguan Tempo. No. 39, Th. XXIII, 27 November 1993.

[7] Habib, A. (2006). Dinamika Hubungan Etnis Tionghoa dan Jawa. Makalah disampaikan pada Seminar Sinologi Tgl. 3-4 Maret 2006. Malang: Lembaga Kebudayaan UMM.

[8] Thung, J.L. (1998). Pengalaman Etnik Tionghoa dalam Pembentukan Identitas (Nasional) Indonesia. Makalah Simposium Etnis Tionghoa sebagai Minoritas di Indonesia. Tanggal 26 Oktober 1998. Depok.

[9] Susetyo, D.P.B. (1999). Asimilasi Etnis Cina di Era Reformasi. Surat Kabar Harian SOLOPOS. 1 Juni 1999.

[10] Verdiansyah, C. (2007). Jalan Panjang Menjadi WNI Catatan Pengalaman dan Tinjauan Kritis. Jakarta: Penerbit Buku Kompas.

[11] Tan, M.G. (1999). Identitas Etnis Tionghoa Pasca Reformasi. dalam Majalah Tempo. Edisi 14-22 Februari 1999.

[12] Hornby, A.S, Gatenby, E.V. and Wakefield, H. (1962). The Aduanced Learner's Dictionary of Current English. London: Oxford Universitry Press.

[13] Sorenson, G. (2003). Demokrasi dan Demokratisasi: Proses dan Prospek dalam Sebuah Dunia yang Sedang Berubah. Terjemahan I Made Krisna. Yogyakarta: Pustaka Pelajar.

[14] Bahmuller, C. F. (1997). "A Framework For Teaching Democratic Citizentship: An International Project". The International Journal of Social Education, 12, 2.

[15] Winataputra, U. S. dan Budimansyah, D. (2007). Civic Education Konteks, Landasan, Bahan Ajar dan Kultur Kelas. PS. PKn SPs UPI.

[16] Cholisin. (2004). "Konsolidasi Demokrasi Melalui Pengembangan Karakter Kewarganegaraan”, Journal Civics Media Kajian Kewarganegaraan Vol I No. 1 Juni 2004. Yogyakarta: Jur. PPKn FIS UNY.

[17] Almond, G. dan Verba, S. (1965). The Civic Culture: Political Attitudes and Democracy in Five Nations. Boston: Little, Brown \& Co.

[18] Winataputra, U. S. (2005). Civic Culture: Muatan Pendidikan Kewarganegaraan sebagai Wahana Menuju Masyarakat Indonesia yang Demokratis. (Makalah). Jakarta: UT. 
[19] Crewell, J. W. (1998). Qualitative Inquiry and Research Design. Choosing Among Five Traditions. Thousand oaks: Sage Publication.

[20] Bogdan, R.C dan Biklen, S.K. (1982). Qualitative Research for Education: An Introduce to Theory and Methods. Boston, Massachusetts: Allyn and Bacon, Inc.

[21] Lincoln, Y.S dan Guba, E.G. (1985). Naturalistik Inquiry. Beverly Hills: Sage Publications.

[22] Miles, M. B dan Huberman, A. M. (1984). Analisis Data Kualitatif. Penerjemah Tjetjep Rohendi Rohidi. Jakarta: UNI Press.

[23] Neuman, W. L. (1997). Social Reserch Methods Qualitative and Quantitative Approach. Boston: Allyn Bacon.

[24] Hogg, M.A dan Abram, D. (1988). Social Identification: A Social Psychology of Intergroup Relation and Group Process. London: Routledge.

[25] Tilaar, H.A.R. (2007). Mengindonesia Etnisitas dan Identitas Bangsa Indonesia. Jakarta: Rineka Cipta.

[26] Weiner, M. (1971). "Political Integration and Political Development", dalam J.L. Finkle dan R.W. Gable, 1968, Political development and Social Change. New York: John Wiley.
[27] Gordon, M. M. (1964). Assimilation in American Life. New York: Oxford University Press.

[28] Wang Gungwu. (1999). "Orang Etnis Tionghoa Mencari Sejarah", dalam I. Wibowo (ed.), Harga yang Harus Dibayar: Sketsa Pergulatan Etnis Tionghoa di Indonesia. Jakarta: P.T. Gramedia.

[29] Cushman \& Wang Gungwu. (1999). Perubahan Identitas Orang Cina Di Asia Tenggara. Jakarta: Grafiti.

[30] Putnam, R.D. (1994). Making Democracy Work. Princeton, N.J : Princeton University Press.

[31] Banks, J. A. (1977). Teaching Strategis for the Social Studies,Inqury, Valuing, and Decion Making. New York \& London: Longman.

[32] Branson, M.S. (1998). The Role of Civic Education, A Forthcoming Education Policy Task Force Position Paper from the Communitarian Network.

[33] Ubaydilah, A.N. (2008). Social Learning at Work. [Online]. Tersedia: http://www.e-psikologi.com.industri detail.asp.171.id [28 Maret 2011]. 